\title{
Visões sobre natureza da ciência em artigos publicados em periódicos nacionais da área de ensino de ciências: um olhar para a educação em química
}

Visions on the nature of science in articles published in brazilian journals of science education: a look in chemistry education

Flavio Tajima Barbosa ${ }^{1}$

Joanez Aparecida Aires ${ }^{2}$

\section{Resumo}

A inserção da abordagem História e Filosofia da Ciência (HFC) no Ensino de Ciências tem recebido atenção por parte dos documentos oficiais, bem como dos pesquisadores da área. Tal abordagem pode possibilitar ao aluno, dentre outras questões, a compreensão sobre o fazer científico e suas limitações, os aspectos históricos envolvidos no seu desenvolvimento e a percepção da Ciência como uma atividade humana. Tendo por base tais considerações, este trabalho objetivou investigar quais visões sobre Natureza da Ciência ( $\mathrm{NdC}$ ) são veiculadas em artigos publicados em periódicos nacionais que tratam da educação em química. Assim, a presente pesquisa tem como objeto artigos que tratam da Educação em Química, publicados em onze dos principais periódicos da área de Ensino de Ciências brasileiro, desde as primeiras publicações de cada revista até o ano de 2015. Os artigos foram analisados segundo "descritores específicos", por meio da Análise Textual Discursiva (ATD). Foram utilizadas duas categorias de análise: visões deformadas, as quais são baseadas nas concepções epistemológicas acerca da $\mathrm{NdC}$ e da construção do conhecimento científico; e, visões de enfrentamento, as quais contrapõem-se às possíveis visões deformadas da $\mathrm{NdC}$. Os resultados demonstram que os artigos que apresentam visões de enfrentamento superam os que apresentaram visões deformadas sobre a Ciência.

Palavras chave: história e filosofia da ciência; natureza da ciência; ensino de química; estado do conhecimento.

\section{Abstract}

The inclusion of the History and Philosophy of Science approach (HFC) in Science Teaching has received attention from the official documents, as well as from the researchers of the area. Such an approach may enable the student, among other issues, to understand the scientific construction and its limitations, the historical aspects involved in its development and the perception of Science as a human activity. Based on these considerations, this work aimed to investigate which visions about Nature of Science $(\mathrm{NdC})$ are shown in articles

\footnotetext{
${ }^{1}$ Universidade Federal do Paraná | tajima.barbosa@gmail.com

${ }^{2}$ Universidade Federal do Paraná | joanez@ufpr.br
} 
published in national journals dealing with chemistry education. Thus, the present research has as its object articles dealing with Chemistry Education, published in eleven of the main journals of the Brazilian Science Teaching area, from the first publications of each journal until the year 2015. The articles were analyzed according to "specific descriptors", through Textual Discursive Analysis (ATD). Two categories of analysis were used: deformed visions, which are based on the epistemological conceptions about $\mathrm{NdC}$ and the construction of scientific knowledge; and, visions of confrontation, which oppose the possible deformed visions of the $\mathrm{NdC}$. The results show that the articles that present visions of confrontation surpass those that presented deformed visions on Science.

Keywords: history and philosophy of science; nature of science; chemistry teaching; state of knowledge.

\section{Introdução}

A História e a Filosofia da Ciência, quando tomadas em conjunto, são instrumentos de grande valia para um melhor entendimento sobre a Natureza da Ciência (NdC) (MATTHEWS, 1995; MARTINS, 2006; MCCOMAS, 2008; PEDUZZI; MARTINS; FERREIRA, 2012). Essas duas áreas de conhecimento se complementam, oferecendo uma possibilidade de mudança no modo de compreender a Ciência e, consequentemente, no modo desta ser ensinada.

A abordagem História e Filosofia da Ciência (HFC) permite que o aluno desenvolva uma concepção mais crítica em relação às Ciências, compreendendo os fatos científicos com que se depara e a maneira pela qual a Ciência é construída. Nesse sentido, tal abordagem permite que o estudante entenda que o conhecimento científico não se constitui de verdades eternas e absolutas, mas de construções dinâmicas que podem se alterar ao longo do tempo. Além disso, de acordo com Henke e Höttecke (2015), esta abordagem permite que se construa visões mais adequadas sobre os aspectos sociais, epistemológicos e metodológicos da Ciência.

Conviver com a diversidade de perspectivas e com a relatividade das teorias, juntamente com a existência de interpretações múltiplas de toda informação, pode contribuir para uma melhoria na educação científica. E para que esse processo de mudança de perspectiva em relação à Ciência ocorra, tanto por parte dos alunos como também dos professores, deve-se, naturalmente, compreender a $\mathrm{NdC}$.

Segundo Moura (2014), a NdC é entendida como um dos aspectos fundamentais no que diz respeito à construção, estabelecimento e organização do conhecimento científico. Refere-se, de uma maneira geral, à epistemologia e à sociologia da Ciência, aos valores e crenças inerentes ao conhecimento científico e seu desenvolvimento. Assim, o objetivo de se abordar a NdC é que os estudantes possam desenvolver uma base conceitual que os permitam compreender a natureza das teorias científicas, "como o homem constrói o conhecimento científico em cada contexto e em cada época, tendo como base suas concepções filosóficas, ideológicas e metodológicas" (MOURA, 2014, p. 37).

Dessa forma, o ensino de Ciências, de acordo com Abd-El-Khalic (2013), pode ser um processo flexível e multidirecional de pensar e aprender, que envolve experiências de aprendizagem que aproximam os estudantes das verdadeiras práticas científicas, ajudandoos a desenvolver um entendimento mais profundo da Ciência e, sobretudo, promovendo o pensamento crítico. A abordagem HFC é um meio de promover um contexto para reflexões 
sobre a NdC, pois permite que se compreenda a importância das observações, da subjetividade, da criatividade e dos aspectos culturais associados ao desenvolvimento do conhecimento científico.

Assim, segundo Höttecke, Henke e Riess (2012), tal abordagem pode possibilitar ao aluno uma melhor compreensão e maior autonomia frente ao mundo científico-tecnológico que o cerca, permitindo que compreenda "a relação dos conteúdos científicos com o contexto social, formando alunos capazes de verem as questões éticas e os efeitos das pesquisas científicas" (GANDOLFl; FIGUEIRÔA, 2013, p.2).

Tendo em vista as potenciais contribuições que a abordagem HFC pode trazer ao Ensino de Ciências, consideramos relevante investigar como tal abordagem vem sendo tratada nas pesquisas da área de Ensino de Ciências. Desse modo, esta pesquisa apresenta um levantamento no qual foram analisados artigos de periódicos de Ensino de Ciências segundo as visões sobre a $\mathrm{NdC}$ neles presentes.

A pesquisa foi realizada a partir de Descritores Específicos, que buscaram fornecer elementos para uma análise histórico-epistemológica dessas produções. Por meio dos descritores, buscou-se conhecer o panorama das publicações em HFC no Ensino de Química nos periódicos da área de Ensino de Ciências.

\section{A natureza da ciência e o ensino de ciências}

A busca pelas características essenciais que definem o conhecimento científico tem sido objeto de pesquisa de filósofos, historiadores, sociólogos e educadores de Ciências que vêem nas visões consensuais sobre a NdC uma possível solução para a crise no Ensino de Ciências. Tais aspectos têm como objetivo ensinar aos alunos de Ciências o modo como o conhecimento científico é construído, fundando-se, para tanto, nos pontos em que há consenso entre os epistemólogos da Ciência. Nesse sentido, estudar a NdC no contexto contemporâneo, segundo Tala e Vesterinen (2015), dá ao estudante condições para que possa interpretar a Ciência de seu tempo, permitindo compreender as aplicações científicas em sua vida cotidiana, participar de discussões públicas sobre a Ciência atual, bem como avaliar o seu impacto na sociedade.

Segundo McCain (2015), as várias disciplinas científicas assemelham-se muito na confiança em evidências, no uso de hipóteses e teorias, na lógica utilizada, dentre outros aspectos. $\mathrm{O}$ autor ainda salienta que as diferentes Ciências se utilizam, em algum momento, de evidências empíricas na explicação de um fenômeno, que devem incluir informações precisas sobre o fenômeno que pretende explicar. Além disso, as disciplinas científicas, em certo ponto, utilizam leis para dar explicações. Todavia, todas essas características comuns ao ensino de ciências podem trazer problemas e/ou distorções para a própria compreensão da Ciência. Em vista disso é que se pode utilizar o conceito de "aspectos consensuais sobre a NdC" no sentido de problematizar o que vem a ser a Ciência.

Gil-Pérez et al. (2001, p. 35) categorizaram uma série de aspectos que foram definidos como "características essenciais do trabalho científico", sendo considerados como elementos fundamentais na compreensão da NdC fornecendo subsídios para que imagens não distorcidas sobre a Ciência sejam veiculadas. Esses autores observam que, apesar das divergências, há aspectos comuns às diferentes vertentes do pensar sobre a Ciência, tratando-se então de "evitar que algumas árvores nos impeçam de ver a floresta". 
Os autores citam como alguns dos aspectos consensuais, o fato de que 0 conhecimento científico tem como característica o pluralismo metodológico, não havendo um único método científico, sendo as hipóteses os guias para a experimentação. O ceticismo em relação aos resultados obtidos também é um pressuposto básico do cientista, que busca encontrar uma coerência global, procurando explicar o maior número de fenômenos possíveis. E deve se atentar ainda que na tentativa de compreender como um fato foi originado, o contexto pode ser analisado de modo a evitar reducionismos. (GILPÉREZ et al., 2001).

Segundo Forato, Pietrocola e Martins, algumas concepções da NdC que são importantes para a formação de professores e alunos incluem

"[...] a compreensão da Ciência como uma atividade humana; entender a Ciência se desenvolvendo em um contexto cultural de relações humanas; conhecer sobre as Ciências e não apenas os conteúdos científicos; possibilitar certo conhecimento metodológico como um antídoto à interpretação empírico-indutivista da Ciência. (FORATO; PIETROCOLA; MARTINS, 2011, p. 32-33)".

Os autores acreditam que esses preceitos sejam básicos para que se possa compreender a $\mathrm{NdC}$. Em oposição ao que geralmente é veiculado nos livros didáticos, onde os cientistas aparecem como grandes homens que, em momentos de insight e isolados, fazem grandes descobertas, a imagem de Ciência que pode ser construída é aquela onde o contexto social exerce influência sobre o cientista. Este, enquanto ser humano e, portanto, sujeito a erros, usa a criatividade e a imaginação na formulação de hipóteses e é também influenciado por outros cientistas, outras ideias, já que não vive num mundo à parte, sendo o empreendimento científico, sobretudo, um empreendimento humano. Nesse sentido é que se faz importante o conhecimento dos processos do fazer científico e não apenas seus produtos, o que pode ser feito por meio do estudo da História da Ciência.

O estudo de textos históricos permite compreender a epistemologia das Ciências por meio do entendimento da mentalidade da época. O aluno pode ser levado a compreender quão complexa e dinâmica é a Ciência, e como ela é influenciada tanto por fatores internos quanto externos, levando em consideração as continuidades e rupturas do desenvolvimento científico. A História da Ciência oferece subsídios para que o processo de construção do conhecimento possa ser compreendido pelo aluno.

De acordo com Saito (2013), as atuais tendências historiográficas tentam compreender a Ciência tal como ela era vista no passado, buscando "contextualizar o conhecimento científico, valorizando o processo de construção deste conhecimento". (SAITO, 2013, p. 190). A Ciência do passado, nessa perspectiva, pode ser estudada levando-se em consideração fatores externos, a lógica interna, as controvérsias, enfim, tudo o que a caracteriza, procurando ser o mais fidedigno possível à época.

No entanto, a História da Ciência esteve durante algum tempo dividida entre os que a analisavam sob aspectos internos e os que a avaliavam sob aspectos externos. A corrente internalista considera que o desenvolvimento científico não é influenciado pela sociedade de seu tempo. A reconstrução histórica nessa perspectiva deve ser racional, omitindo tudo que não diga respeito à própria Ciência. Já a perspectiva dita externalista acerca da História da Ciência, interessa-se pelos fatores não-intelectuais, sejam eles econômicos, políticos, sociais, e até mesmo religiosos presentes no desenvolvimento científico. Considera a Ciência como sendo uma atividade humana, repleta de subjetividade e que é influenciada pelo 
contexto em que se desenvolve, sendo, portanto, necessária uma análise social da prática científica.

Conforme argumentam Beltran, Saito e Trindade (2014):

A corrente internalista pressupõe que a ciência seja autônoma, neutra e tenha uma dinâmica própria, independente da sociedade que a gerou. Desse modo, deve ser estudada em função dos seus próprios objetos. Já a perspectiva externalista, analisa a ciência como uma atividade humana que, para ser compreendida, precisa ser estudada no conjunto social, político e econômico da época (BELTRAN; SAITO; TRINDADE, 2014, p. 37).

Assim, ambas as correntes devem ser levadas em consideração ao se fazer História da Ciência. Desse modo, um ensino que esteja preocupado em discutir sobre a Ciência pode levar em consideração tanto os fatores internos quanto os fatores externos do fazer científico, já que o contexto histórico permite avaliar o processo científico, os elementos subjetivos, econômicos, culturais e filosóficos que estão presentes neste meio e que influenciam os trabalhos desenvolvidos. Nesse sentido, episódios da História da Ciência permitem "examinar a Ciência como uma atividade passível de subjetividade e possibilitam compreender a incoerência da separação entre o contexto da descoberta e da justificativa na análise do desenvolvimento da Ciência". (RAICIK; PEDUZZI, 2014, p. 30).

Por fim, destacamos que o conhecimento científico surge das relações de complementaridade e oposição existentes entre a razão, a experiência, a imaginação e a verificação. Esse conhecimento não pode, de modo algum, ser dissociado da vida humana e das relações sociais. O professor de Ciências deve mostrar ao aluno que a Ciência desenvolvida em laboratórios não está alheia aos problemas sociais, econômicos e políticos, e que, na maioria das vezes, é influenciada por estes fatores. Desse modo, conhecer em alguma medida como se dá o desenvolvimento de uma teoria científica, assim como o fato de não haver algum tipo de mecanismo regulador específico que dite a maneira como o método científico é utilizado pelos cientistas, e que a Ciência depende em grande parte de aspectos que não podem ser generalizados, pode ajudar o aluno de Ciências a compreender melhor o conteúdo específico que está sendo estudado.

\section{Metodologia}

Este trabalho objetivou verificar as visões de $\mathrm{NdC}$ presentes em artigos publicados em periódicos nacionais da área de Ensino de Ciências, no período de 1985 a 2015. Para a localização de tais artigos foi realizada consulta em onze desses periódicos, listados no Quadro 1.

A seleção dos artigos foi realizada com base nas palavras-chave História e Filosofia da Ciência, História da Ciência, Filosofia da Ciência, Natureza da Ciência, presentes no título, resumo e palavras-chave. Quando a compreensão do assunto abordado no artigo não era clara, devido à ausência de informações nessas fontes, lia-se o artigo na íntegra para uma melhor compreensão e categorização. Nessa leitura o foco estava na centralidade da presença da temática HFC nas discussões apresentadas pelos autores. 


\begin{tabular}{l|c}
\hline REVISTA/Sigla & $\begin{array}{c}\text { QUALIS CAPES } \\
\text { ENSINO (2016) }\end{array}$ \\
\hline Ciencia \& Educação (C\&E) & $\mathrm{A} 1$ \\
\hline Amazônia - Revista de Educação em Ciências e Matemáticas (AMZ) & $\mathrm{A} 2$ \\
\hline Ensaio - Pesquisa em Educação em Ciências (EPEC) & $\mathrm{A} 2$ \\
\hline Investigações em Ensino de Ciências (IENCI) & $\mathrm{A} 2$ \\
\hline Revista Brasileira de Pesquisa em Ensino de Ciências (RBPEC) & $\mathrm{A} 2$ \\
\hline Acta Scientiae (AS) & $\mathrm{B} 1$ \\
\hline Alexandria (Alxd) & $\mathrm{B} 1$ \\
\hline Experiências em Ensino de Ciências (EENCI) & $\mathrm{B} 1$ \\
\hline Química Nova na Escola (QNEsC) & $\mathrm{B} 1$ \\
\hline Revista Brasileira de História da Ciência (RBHC) & $\mathrm{B} 1$ \\
\hline História da Ciência e Ensino (HC\&E) & $\mathrm{B} 4$ \\
\hline
\end{tabular}

Quadro 1- Revistas de Ensino de Ciências

Em um primeiro momento da pesquisa, foram selecionados todos os artigos que tratavam da abordagem HFC no Ensino de Ciências. Posteriormente, foram selecionados apenas os que tratavam do Ensino de Química. O quadro 2 apresenta o resultado deste levantamento. Apenas 2,54\% do total de artigos pesquisados tratam da abordagem HFC no Ensino de Química, ou seja, de um total de 3628 artigos pesquisados, apenas 92 constituem-se como objeto de investigação desta pesquisa.

\begin{tabular}{l|c|c|c}
\hline Revista (Sigla) & $\begin{array}{c}\text { Total de } \\
\text { Artigos }\end{array}$ & $\begin{array}{c}\text { Artigos HFC } \\
\text { Química }\end{array}$ & $\begin{array}{c}\text { \% Artigos HFC } \\
\text { Química }\end{array}$ \\
\hline HC\&E & 71 & 22 & $30,99 \%$ \\
\hline QNEsC & 626 & 49 & $7,83 \%$ \\
\hline AS & 312 & 5 & $1,60 \%$ \\
\hline RBPEC & 359 & 4 & $1,11 \%$ \\
\hline AMZ & 127 & 2 & $1,57 \%$ \\
\hline C\&E & 672 & 5 & $0,74 \%$ \\
\hline RBHC & 300 & 2 & $0,67 \%$ \\
\hline EPNCl & 373 & 2 & $0,54 \%$ \\
\hline Alxd & 335 & 1 & $0,30 \%$ \\
\hline EENCl & 188 & 0 & $0,00 \%$ \\
\hline Total de & 265 & 0 & $0,00 \%$ \\
Artigos & 3628 & 92 & $2,54 \%$ \\
\hline
\end{tabular}

Quadro 2 - Número total de artigos publicados sobre HFC no Ensino de Química em cada revista no período analisado

Esses dados demonstram que os principais periódicos da área de Ensino de Ciências brasileiros apresentam artigos que tratam do tema desta investigação, com destaque para as revistas HC\&E e QNEsc, que juntas publicaram 77,17\% dos trabalhos analisados por esta pesquisa, ou 71 artigos. Em valores absolutos, a QNEsc foi a que mais publicou artigos no período analisado, com um total de 49. No entanto, levando-se em consideração que os outros oito periódicos publicaram juntos apenas 21 artigos referentes à abordagem HFC no Ensino de Química, há um indicativo de escassez de pesquisas que tratam do tema em 
periódicos sobre ensino de ciências no pais, uma vez que a HC\&E é uma revista que trata especificamente da temática HFC. Esta constatação é preocupante, pois nos leva a inferir que tal tema não vem sendo objeto de estudo do grande corpo de pesquisadores da área, mesmo sendo a questão da $\mathrm{NdC}$, um dos problemas centrais do ensino de ciências.

Em seguida, a partir de Descritores Específicos, buscou-se identificar as concepções sobre NdC presentes nos artigos, por meio de uma análise epistemológica das categorias relacionadas a essas concepções. Para a análise desses descritores foi utilizada a Análise Textual Discursiva (ATD).

As categorias de análise foram elaboradas por Silva (2014), as quais tiveram por base o trabalho de Gil-Pérez et al. (2001). Tais categorias são apresentadas no Quadro 3. Neste Quadro, as categorias apresentam duas definições: A primeira - 'Origem/explicação da Categoria', a qual é baseada nas concepções epistemológicas acerca da $\mathrm{NdC}$ e da construção do conhecimento científico, que podem ser transmitidas na educação em Ciências por omissão ou reforço. A segunda - 'Enfrentamento', a qual contrapõe-se às possíveis visões deformadas sobre NdC.

\begin{tabular}{|c|c|c|}
\hline Categoria & Origem/explicação da Categoria & Enfrentamento \\
\hline $\begin{array}{l}\text { Ciência não } \\
\text { influenciada por } \\
\text { fatores externos }\end{array}$ & $\begin{array}{l}\text { Surge da visão descontextualizada, na } \\
\text { qual o trabalho científico é } \\
\text { apresentado fora do seu contexto } \\
\text { histórico, filosófico, social, político, } \\
\text { cultural, econômico de produção, no } \\
\text { qual a tecnologia é considerada uma } \\
\text { mera aplicação dos conhecimentos } \\
\text { científicos. }\end{array}$ & $\begin{array}{l}\text { Esta concepção pode ser enfrentada } \\
\text { quando se considera que a Ciência é } \\
\text { influenciada por fatores externos- } \\
\text { contexto histórico, filosófico, social, } \\
\text { político, cultural, econômico de produção, } \\
\text { no qual se verifica independência histórica } \\
\text { da tecnologia em relação à Ciência. }\end{array}$ \\
\hline $\begin{array}{l}\text { Ciência como } \\
\text { atividade } \\
\text { individual. }\end{array}$ & $\begin{array}{l}\text { Origina-se da visão individualista e } \\
\text { elitista, na qual a produção científica } \\
\text { é vista como uma atividade } \\
\text { individual, podendo incorrer numa } \\
\text { visão estereotipada do cientista. } \\
\end{array}$ & $\begin{array}{l}\text { Esta concepção pode ser enfrentada } \\
\text { quando se apresenta a Ciência como } \\
\text { atividade coletiva, considerando o } \\
\text { intercâmbio de ideias entre os cientistas. }\end{array}$ \\
\hline $\begin{array}{l}\text { Observação } \\
\text { neutra e em } \\
\text { busca da } \\
\text { descoberta } \\
\text { científica. }\end{array}$ & $\begin{array}{l}\text { Surge da visão empírico-indutivista e } \\
\text { ateórica, a qual considera a Ciência } \\
\text { isenta de interesses, em busca do } \\
\text { "descobrimento". Enfatiza o papel } \\
\text { "neutro" da observação e da } \\
\text { experimentação, desconsiderando o } \\
\text { papel essencial das hipóteses e das } \\
\text { teorias, que orientam todo o } \\
\text { processo. }\end{array}$ & $\begin{array}{l}\text { Esta concepção pode ser enfrentada } \\
\text { quando se considera que toda } \\
\text { observação é influenciada por uma teoria, } \\
\text { ou seja, não existe neutralidade na } \\
\text { Ciência, de forma que as hipóteses atuam } \\
\text { como orientadoras da investigação. }\end{array}$ \\
\hline $\begin{array}{l}\text { Método científico } \\
\text { clássico }\end{array}$ & $\begin{array}{l}\text { Origina-se da visão rígida, que } \\
\text { considera o método científico como } \\
\text { uma única sequência de etapas fixas } \\
\text { e bem definidas. }\end{array}$ & $\begin{array}{l}\text { Esta concepção pode ser enfrentada } \\
\text { quando se apresenta o pluralismo } \\
\text { metodológico, evidenciando o fato de } \\
\text { que não há um único método que } \\
\text { garanta o desenvolvimento do } \\
\text { conhecimento científico. }\end{array}$ \\
\hline
\end{tabular}




\begin{tabular}{|l|l|l|}
\hline $\begin{array}{l}\text { Conhecimento } \\
\text { científico } \\
\text { verdadeiro e } \\
\text { definitivo. }\end{array}$ & $\begin{array}{l}\text { Surge da visão aproblemática e } \\
\text { ahistórica, na qual a Ciência é } \\
\text { apresentada como um conjunto de } \\
\text { conhecimentos elaborados e } \\
\text { definitivos, sem referir aos problemas } \\
\text { que Ihes deram origem, à sua } \\
\text { evolução e às dificuldades } \\
\text { encontradas. }\end{array}$ & $\begin{array}{l}\text { Esta concepção pode ser enfrentada } \\
\text { quando se apresenta a Ciência dinâmica, } \\
\text { com referência aos problemas que lhe } \\
\text { deram origem, sua evolução, dificuldades } \\
\text { encontradas, bem como as limitaçães ou } \\
\text { possíveis perspectivas. }\end{array}$ \\
\hline $\begin{array}{l}\text { Fragmentação } \\
\text { e/ou } \\
\text { simplificação do } \\
\text { conhecimento. } \\
\text { analítica, na qual o trabalho científico } \\
\text { é visto de forma compartimentalizada } \\
\text { e simplista, numa tendência à } \\
\text { perspectiva epistemológica } \\
\text { reducionista, na qual o todo pode ser } \\
\text { compreendido pelo conhecimento } \\
\text { das partes. }\end{array}$ & $\begin{array}{l}\text { Esta concepção pode ser enfrentada } \\
\text { quando se apresenta os processos de } \\
\text { unificação do conhecimento em } \\
\text { diferentes campos da Ciência e a } \\
\text { construção de corpos coerentes de } \\
\text { conhecimento (teorias) cada vez mais } \\
\text { amplos. Dessa forma, também se enfrenta } \\
\text { a posição epistemológica reducionista. }\end{array}$ \\
\hline $\begin{array}{l}\text { Surge da visão cumulativa e linear, } \\
\text { onde o conhecimento científico é } \\
\text { visto como fruto de um crescimento } \\
\text { linear e cumulativo, sem considerar as } \\
\text { crises, rupturas, continuidades e } \\
\text { controvérsias. }\end{array}$ & $\begin{array}{l}\text { Esta concepção pode ser enfrentada } \\
\text { quando se apresenta o conhecimento } \\
\text { científico como resultado de processos de } \\
\text { questionamentos, mudanças, crises, } \\
\text { rupturas, continuidades e controvérsias. }\end{array}$ \\
$\begin{array}{l}\text { Acredita-se que a realidade existe } \\
\text { independentemente da cognição e } \\
\text { que as entidades teóricas da Ciência } \\
\text { são reais, devem ser descobertas e } \\
\text { podem descrever o mundo como ele } \\
\text { realmente é. }\end{array}$ & $\begin{array}{l}\text { Esta concepção pode ser enfrentada } \\
\text { quando se demonstra que a criatividade e } \\
\text { a imaginação têm um papel importante } \\
\text { na Ciência, já que teorias, modelos e leis } \\
\text { vão muito além de observações e dados } \\
\text { experimentais, e por isso, não são } \\
\text { redutíveis a uma objetividade intrínseca. }\end{array}$ \\
\hline Realismo
\end{tabular}

Quadro 3 - Categorias a priori definidas para análise das concepções sobre NdC presentes nos artigos. Adaptado de Silva (2014).

No Quadro 4, encontra-se uma síntese dos dois conjuntos de categorias utilizados na análise desenvolvida nesta pesquisa.

\begin{tabular}{|l|l|}
\hline $\begin{array}{l}\text { CATEGORIAS REFERENTES A VISÕES } \\
\text { DEFORMADAS SOBRE A CIÊNCIA }\end{array}$ & $\begin{array}{l}\text { CATEGORIAS REFERENTES AO } \\
\text { ENFRENTAMENTO/SUPERAÇÃO DE VISÕES } \\
\text { DEFORMADAS SOBRE A CIÊNCIA }\end{array}$ \\
\hline Ciência não influenciada por fatores externos. & Ciência influenciada por fatores externos. \\
\hline Ciência como atividade individual. & Ciência como atividade coletiva. \\
\hline $\begin{array}{l}\text { Observação neutra e em busca da } \\
\text { descoberta científica. }\end{array}$ & Observação influenciada por uma teoria. \\
\hline Método científico clássico. & Pluralismo metodológico. \\
\hline $\begin{array}{l}\text { Conhecimento científico verdadeiro e } \\
\text { definitivo. }\end{array}$ & Caráter histórico e dinâmico da Ciência. \\
\hline $\begin{array}{l}\text { Fragmentação e/ou simplificação do } \\
\text { conhecimento. }\end{array}$ & Unificação do conhecimento científico. \\
\hline Linearidade da Ciência. & Rupturas e/ou controvérsias científicas. \\
\hline Realismo Ingênuo & Ciência como atividade imaginativa e criativa \\
\hline
\end{tabular}

Quadro 4 - Categorias a priori utilizadas para análise das concepções sobre NdC presentes nos artigos, Adaptado de Silva (2014). 
Estas categorias permitiram a análise das concepções sobre NdC presentes nos artigos, as quais serão apresentadas a seguir.

\section{Resultado das visões sobre $\mathrm{NdC}$ presentes nos artigos}

Os Quadros 5 e 6 a seguir mostram os resultados quantitativos de cada uma das concepções sobre $\mathrm{NdC}$ presentes nos artigos. Por meio destes, podemos verificar que as visões deformadas aparecem em menor quantidade do que as visões de enfrentamento. A seguir detalharemos algumas das categorias de visões deformadas.

\begin{tabular}{l|c}
\hline Visões Deformadas & No Artigos \\
\hline Ciência não influenciada por fatores externos & 14 \\
\hline Observação neutra e em busca da descoberta científica & 11 \\
\hline Linearidade da Ciência & 11 \\
\hline Ciência como atividade individual & 9 \\
\hline Método científico clássico & 8 \\
\hline Whiggismo (emergente) & 7 \\
\hline Conhecimento científico verdadeiro e definitivo & 6 \\
\hline Realismo Ingênuo & 5 \\
\hline Fragmentação e/ou simplificação do conhecimento & 0 \\
\hline
\end{tabular}

Quadro 5 - Quantitativo de Visões Deformadas presentes nos artigos

\begin{tabular}{l|c}
\hline Visões Enfrentamento & No Artigos \\
\hline Caráter histórico e dinâmico da Ciência & 78 \\
\hline Ciência como atividade coletiva & 55 \\
\hline Ciência influenciada por fatores externos & 51 \\
\hline Rupturas e/ou controvérsias científicas & 48 \\
\hline Observação influenciada por uma teoria & 34 \\
\hline Pluralismo metodológico & 26 \\
\hline Unificação do conhecimento científico & 26 \\
\hline Ciência como atividade imaginativa e criativa & 17 \\
\hline Modelos como representação da realidade (emergente) & 18 \\
\hline Ciência como atividade humana (emergente) & 8 \\
\hline
\end{tabular}

Quadro 6 - Quantitativo de Visões de Enfrentamento presentes nos artigos

A categoria de Visão Deformada: Ciência não influenciada por fatores externos é a que possui maior recorrência, com frequência de 14 artigos. Possivelmente, essa maior recorrência se deva a uma herança do peso e influência de uma historiografia da ciência mais antiga, a qual levava em consideração somente as influências internas da própria Ciência como fator de mudança no campo científico, aspectos característicos da abordagem internalista. A nova historiografia, por outro lado, começa a analisar o desenvolvimento do pensamento científico buscando salientar também as influências externas ao meio científico, como os meios cultural e social da época em que ocorreu a construção do conhecimento, aspectos que caracterizam a abordagem externalista. Ou seja, esta abordagem talvez ainda 
não esteja tão presente justamente por estar à sombra da hegemonia da compreensão internalista. Uma possível consequência dessa compreensão, é a manutenção dessa Visão Deformada e não o enfrentamento desta, embora consideremos atualmente que nem aspectos somente internos ou somente externos sejam fatores determinantes na construção do conhecimento, mas ambos.

Em seguida aparece a categoria de Visão Deformada: Observação neutra e em busca da descoberta científica, constatada 11 vezes nos artigos analisados. Os artigos enquadrados nessa categoria apresentam o cientista como alguém que, apenas observando os fenômenos naturais, "descobriu" regularidades e padrões, e assim foi capaz de formular leis científicas e desenvolver teorias.

Os artigos apresentados na categoria de Visão Deformada: Linearidade da Ciência, com frequência igual a 11, mostram a Ciência a partir de uma perspectiva cumulativa, linear, sem controvérsias ou rupturas. O desenvolvimento científico aparece sempre de maneira a complementar os feitos anteriores, sendo aperfeiçoado a cada etapa. De fato, o conhecimento sempre se aperfeiçoa, no entanto, em muitos episódios históricos, como hoje se conhece pela historiografia da Ciência, houve momentos de rupturas, onde o conhecimento até então vigente é substituído por outro. Evidentemente, essa substituição não se dá abruptamente, mas de maneira gradual, até que o paradigma antigo seja substituído pelo novo.

Comparando-se os resultados das Visões Deformadas com a categoria Visões de Enfrentamento, há um número relativamente menor de artigos que apresentam visões deformadas de Ciência do que os que apresentam concepções de enfrentamento, ou seja, menos ingênuas do fazer científico. Salienta-se que um mesmo artigo pode ter apresentado tanto visões deformadas quanto visões de enfrentamento, já que, por exemplo, a História da Ciência pode ter sido apresentada de maneira linear em alguns trechos, seguida de rupturas e controvérsias em outros.

De maneira geral, pode-se dizer que todos os artigos apresentam concepções sobre $\mathrm{NdC}$ que ajudam a transmitir uma visão menos ingênua do fazer científico e que colaboram para que os estudantes não possuam como única concepção de Ciência, aquela empíricoindutivista, ainda influente em nossas instituições de ensino, tanto em nível médio, quanto superior.

No que diz respeito às visões de enfrentamento, o fato de a Ciência possuir um caráter histórico e dinâmico está presente em 78 dos 90 artigos analisados nessa pesquisa, ou seja, 86,66\% dos artigos procuraram mostrar como a Ciência não é pronta e acabada e como o processo pelo qual se dá a produção do conhecimento científico depende de uma atividade que vem se dando ao longo dos séculos.

O caráter coletivo da Ciência está presente em 55 artigos, e mostra o fato de que a Ciência não é produzida de maneira individual, por grandes gênios enclausurados em torres de marfim e que em um súbito momento de inspiração fazem descobertas revolucionárias. Os artigos mostram como a Ciência é feita de várias mentes, várias pessoas que contribuem para que uma teoria, um modelo, um experimento seja concretizado, fazendo avançar a Ciência e o conhecimento sobre a natureza. Nos artigos percebe-se como o trabalho de diferentes cientistas é necessário para o avanço do conhecimento científico. Baseado em obras de outros autores é que os cientistas desenvolvem suas pesquisas, continuando-as ou refutando-as fazendo com que explicações mais abrangentes dos fenômenos físicos possam ser construídas. Há a preocupação em apresentar os cientistas como membros de uma 
comunidade que busca solucionar os problemas determinados pelo paradigma vigente. As questões científicas de uma determinada época não são determinadas por uma dúvida que assola um único cientista, mas são sim, problemas atestados pela coletividade de praticantes da área.

Outro aspecto da $\mathrm{NdC}$ que aparece com bastante frequência são as rupturas e/ou controvérsias científicas, presentes em 48 dos artigos. Estes artigos mostram como a História da Ciência não é linear, como teorias são "abandonadas" em favor de outras, dependendo muitas vezes de fatores extracientíficos. Nos artigos identifica-se como o pensamento divergente se faz tão importante à construção do conhecimento científico, já que permite aos cientistas perceberem aspectos de um determinado fenômeno que o outro não havia levado em consideração. Como no caso das rupturas, onde uma explicação que até então era tida como a única possível, é confrontada com dados que não corroboram com aquela teoria. Nesse caso, novas explicações são necessárias, podendo inclusive ir contra a teoria vigente.

Fatores externos, como política, economia, religião, dentre outros, estão presentes em 51 artigos. Esses fatores permitem vislumbrar o fato de que a Ciência está inserida em determinada sociedade e época e que, muitas vezes, o seu desenvolvimento se dá a partir de problemas que surgem no seio da sociedade e que dependem de soluções científicas para serem solucionados.

As outras categorias, tanto de visões deformadas quanto de enfrentamento são comentadas adiante, uma a uma, por meio dos resultados obtidos com a ATD.

\section{Exemplos de visões deformadas e de enfrentamento}

Nesta seção são apresentados exemplos das Visões Deformadas e de Enfrentamento sobre a NdC localizados nos artigos analisados.

\section{Exemplos de visões deformadas}

Consideramos que a presença destas visões deformadas se deve, dentre outros fatores, ao número reduzido de profissionais que produzem História da Ciência no Brasil. Avaliamos que pesquisadores das áreas "duras" com interesse em História da Ciência, porém sem uma formação histórico-filosófica, acabam produzindo artigos que podem distorcer os fatos históricos. Destacamos, no entanto, que, mesmo que tais publicações apresentem erros históricos, tendo os professores uma formação que Ihes permita identificar tais erros, estes poderão utilizar os artigos, pois saberão explorar as potencialidades ali presentes.

\section{Ciência não influenciada por fatores externos}

Nessa categoria aparecem os artigos que, ao apresentarem a construção de um relato histórico, deixam de levar em consideração aspectos externos do fazer científico. Os artigos voltam-se para uma perspectiva internalista, na qual apenas os desenvolvimentos de caráter puramente científico importam para a consolidação ou ruptura de uma teoria.

Nesse sentido, a contribuição de Aston para a descoberta dos isótopos não-radioativos corresponde a um esforço planejado e à busca de uma solução para uma disputa travada, à época, no seio da Ciência, a respeito 
da inexatidão dos valores dos então denominados pesos atômicos dos elementos (MEDEIROS, 1999, p. 32)

O artigo revela a ausência de qualquer tipo de menção a alguma causa política, econômica, ou até mesmo religiosa, que possa ter influenciado o desenvolvimento dos isótopos. Apesar de não ser um fator determinante, o contexto da descoberta pode ser influenciado por motivos que não estão diretamente ligados ao fazer científico. Nesse sentido, ao leitor do artigo pode parecer que o cientista desenvolveu sua teoria dentro de uma redoma de vidro, tendo como única motivação disputas internas ao próprio fazer científico.

\section{Ciência como atividade individual}

Nessa categoria, enquadram-se nove artigos, nos quais a Ciência é apresentada como produto da mente de grandes gênios que trabalham de maneira isolada.

Em um artigo (CHAGAS, 2001), embora o autor destaque os grandes feitos de van't Hoff, o que se percebe é que há uma grande preocupação em enaltecer a figura do cientista, apresentando os grandes feitos de maneira acumulativa e linear. O autor, apesar de citar que alguns livros de van't Hoff não fizeram sucesso em um primeiro momento, não entra em maiores detalhes a respeito da vida pessoal do cientista, apenas no momento da introdução, pois faz referência somente a alguns breves dados biográficos. Não apresenta controvérsias, disputas e nem pensamento divergentes que envolveriam o cientista, ficando o relato limitado a apresentar o cientista como um grandioso homem da Ciência, que ganhou o Prêmio Nobel por sua genialidade. Não é possível inferir do texto, que van't Hoff era uma pessoa comum, com medos, anseios, angústias e dúvidas a respeito de seu próprio trabalho.

Outro exemplo (GOUVEIA-MATOS, 1997), que apresenta os trabalhos de Pasteur, e da mesma maneira, mostra o cientista como alguém responsável por todo o desenvolvimento de uma determinada área científica: "Em todas essas etapas, ao fundar a microbiologia e posteriormente a imunologia, Pasteur exerceu um papel preponderante". (GOUVEIAMATOS, 1997, p. 21). Nesse sentido, o trecho em destaque faz transparecer ao leitor que Pasteur fundou a microbiologia e a imunologia sozinho, sem entrar no mérito que ele pertencia a uma comunidade científica e que, portanto, trabalhava com a ajuda de outros cientistas.

Em outro artigo (BAGATIN et al., 2005), Pasteur também é apresentado como um cientista de grandes feitos que, como pode ser verificado no excerto abaixo, realizou sozinho uma verdadeira revolução na área de saúde, sem a ajuda de colaboradores:

Felizmente Pasteur abandonou esse estranho experimento para se dedicar mais intensamente ao seu importante trabalho em Microbiologia, sendo responsável por uma das maiores, senão a maior, revolução na área de saúde pública: Pasteur descobriu que os micróbios são causadores de sérias doenças que já tinham levado à morte centenas de milhares de pessoas no mundo todo. (BAGATIN et al., 2005, p. 36).

Outro artigo (GORRI; SANTIN FILHO, 2009) também enaltece a figura do cientista, no qual Priestley, que durante muitos anos realizou estudos sobre gases, é exaltado como o maior de sua época: "Entretanto, em termos de número de 'ares' estudados, Priestley superou todos os seus antecessores". (GORRI; SANTIN FILHO, 2009, p. 188). 
O que pode se concluir a partir da leitura dos artigos selecionados nessa categoria é que os cientistas são pessoas com características incomuns, excêntricos e que por meio de súbitos momentos de iluminação realizam seus grandes feitos.

\section{Observação neutra e em busca da descoberta científica}

Artigos que apresentam o cientista como alguém que, apenas observando os fenômenos naturais, encontrou regularidades e padrões, e assim foi capaz de encontrar leis científicas e desenvolver teorias, enquadram-se nessa categoria.

Como exemplo cita-se o episódio da descoberta da estrutura do DNA por Watson e Crick. O fragmento abaixo demonstra como os autores apresentam a observação independente da teoria, como se o simples fato de observar permitisse ao cientista compreender um determinado fenômeno.

Ele também pôde observar que a composição de bases do DNA numa dada espécie não muda com a idade do organismo, estado nutricional ou mudanças ambientais. Sua observação mais importante, porém, talvez tenha sido de que em todos os DNA celulares, não importa qual a espécie, o número de bases adenina é igual ao de timina $(A=T)$ e o de guanina é igual ao de citosina ( $G=C$ ). (THIEMANN, 2003, p. 15).

No excerto, os autores não citam o fato de que a observação sempre é influenciada por uma teoria, e que sem uma hipótese em mente, o cientista não tem como orientar suas observações.

Outro artigo (FILGUEIRAS, 2004) também apresenta essa perspectiva de maneira ainda mais latente, mostrando como Dalton foi capaz de descobrir leis sobre a composição de gases apenas realizando observações: "Curiosamente, a composição do ar era praticamente constante, como mostravam as abundantes observações de Dalton realizadas em lugares os mais distantes entre si". (FILGUEIRAS, 2004, p. 41). Aqui, as observações falam por si só, o que se sabe não ser possível.

Um último exemplo retrata Cavendish apenas observando o resultado de uma reação e tirando conclusões: "Reagindo metais com soluções de ácidos diluídos, Henry Cavendish observou a evolução de um gás de densidade extremamente baixa e muito inflamável". (GORRI; SANTIN FILHO, 2009, p. 188).

Assim, os artigos selecionados nessa categoria enfatizam o papel neutro e desinteressado das observações, desconsiderando o papel essencial das hipóteses e das teorias, que orientam todo o processo.

\section{Método científico clássico}

Os artigos pertencentes a essa categoria mostram de maneira explícita o método científico clássico.

Um dos artigos (ROQUE, 2007) descreve o roteiro da peça teatral "Uma festa no céu" que é uma adaptação livre da história da química no século XVIII. Escrita ao final de um curso desenvolvido pela autora em uma disciplina de Química por meio do teatro, ela aborda a química dos gases desenvolvida por Black, Scheele, Priestley, Cavendish e Lavoisier, além das ideias iniciais do átomo propostas por Dalton. Bohr aparece em cena como um organizador das percepções químicas e Boyle, como um dos precursores da Química Pneumática, que tem também o seu espaço em cena. A autora apresenta uma 
concepção de método científico, fortemente arraigada em uma concepção empíricoindutivista: "A Ciência funciona assim: nós observamos um fato, propomos uma teoria e depois temos que comprová-la experimentalmente". (ROQUE, 2007, p.33).

Pelo excerto verifica-se que para a autora, a observação é o primeiro momento da descoberta científica, seguida da construção de uma teoria que explique os fenômenos, e que depois é comprovada pelo experimento. Sabe-se que de acordo com os teóricos da moderna Filosofia da Ciência, isso não é verdade, e que não existe observação neutra e nem experimentos ditos "cruciais".

Outro artigo (FARIAS, 2001) que é influenciado pela concepção empírico-indutivista mostra o papel da intuição na construção do conhecimento científico, apresentando a história dos compostos de coordenação:

Jørgensen era o tipo de pesquisador para o qual a teoria nunca pode avançar mais do que os dados experimentais disponíveis o permitem. Para ele (e muitos de nós) a experiência pavimenta o caminho seguro por meio do qual, só então, a teoria irá seguir". (FARIAS, 2001, p. 32).

O autor, no trecho selecionado, salienta o fato de que o método científico é feito de uma única sequência de etapas fixas e bem definidas, e que os experimentos determinam o surgimento de uma teoria.

Em um outro artigo (BAGATIN et al., 2005), o autor parece transparecer o fato de que os experimentos falam por si só: "Os experimentos com os tartaratos claramente sugeriam uma estreita correlação entre configuração molecular, atividade óptica e estrutura cristalina". (BAGATIN et al., 2005, p. 36). Nesse sentido, percebe-se que por meio do exemplo o autor considera a Ciência como sendo algorítmica, de modo que o desenvolvimento de uma teoria científica decorre da coleta sucessiva de dados.

\section{Conhecimento científico verdadeiro e definitivo}

A categoria Conhecimento científico verdadeiro e definitivo é composta pelos artigos que consideram os resultados da Ciência como verdades eternas e imutáveis, ou como uma aproximação sempre contínua da verdade que está velada pela natureza.

Em um artigo (THIEMANN, 2003) encontra-se um trecho no qual o conhecimento científico é passível de testes que comprovem sua veracidade:

O experimento definitivo surgiu somente em 1952, com os elegantes experimentos de Alfred Hershey (1908-1997) e Martha Chase (1930- ). Dessa forma, ficou consolidada a noção de que o material genético é constituído de moléculas de DNA e não de proteínas, como alguns pesquisadores ainda acreditavam até então. (THIEMANN, 2003, p. 15).

No entanto, como bem salientam Praia, Cachapuz e Gil-Pérez (2002), a experiência científica é orientada e mesmo valorizada pelo enquadramento teórico do sujeito, e dessa maneira, os resultados obtidos dizem respeito aos métodos e às técnicas utilizadas pelo cientista e não a uma resposta definitiva em relação à realidade: "os seus resultados são lidos como elementos (possíveis) de construção de modelos interpretativos do mundo e não cópias (e muito menos fiéis) do real" (PRAIA; CACHAPUZ; GIL-PÉREZ, p. 257, 2002). Dessa maneira, o conhecimento científico está muito mais inserido num processo de construção do que num resultado final. 


\section{Linearidade da Ciência}

Os artigos apresentados na categoria Linearidade da Ciência mostram a Ciência a partir de uma perspectiva cumulativa, linear, sem controvérsias ou rupturas. $O$ desenvolvimento científico aparece sempre de maneira a complementar os feitos anteriores, sendo aperfeiçoado a cada etapa. De fato, o conhecimento sempre se aperfeiçoa, no entanto, em muitos episódios históricos, como hoje se conhece pela historiografia da Ciência, houve momentos de rupturas, onde o conhecimento até então vigente é substituído por outro. Evidentemente, essa substituição não se dá abruptamente, mas de maneira gradual, até que o paradigma antigo seja substituído pelo novo.

Um artigo (CHAGAS, 2011) ilustra bem essa concepção. No excerto a seguir, o autor apresenta o desenvolvimento da Ciência de maneira linear, como se o conhecimento tivesse chego até nós cumulativamente: "A crença na existência de átomos, partículas últimas da matéria, existiu desde Antiguidade. Durante a Idade Média europeia ela esteve meio esquecida, voltando depois com o Renascimento". (CHAGAS, 2011, p. 7).

Assim, pode-se ver como a ideia de que o conhecimento sempre esteve presente e foi revivido, aparece de maneira linear, como se o conhecimento da Antiguidade fosse o mesmo do que o que foi revivido no Renascimento. Apesar de alguns conceitos serem semelhantes, não é possível dizer que eram os mesmos, já que, sendo o conhecimento dependente das épocas e condições em que é produzido, torna-se errôneo considerá-los iguais.

\section{Realismo Ingênuo}

Nessa categoria os modelos científicos são cópias fiéis da realidade. Os átomos são partículas que realmente existem, ao invés de serem constructos teóricos que procuram representar a realidade. Os objetos criados pela Ciência aparecem como tendo existência real, sendo que o cientista vai gradativamente retirando o véu que oculta a realidade última da natureza.

No excerto abaixo, que trata da rotação da luz polarizada por moléculas quirais, o autor apresenta o fato de que o fenômeno é realmente devido à estrutura molecular.

O que se constata nesses casos é que não são apenas cristais ou líquidos puros que causam rotação da luz, mas também soluções de algumas moléculas, o que indica que o fenômeno não se deve à estrutura cristalina ou a um arranjo especial do líquido, mas é decorrente da estrutura molecular em si; isto é, algumas moléculas exibem atividade óptica. (BAGATIN et al., 2005, p. 35).

O leitor desavisado pode concluir sobre a existência real das moléculas, ao invés de concebê-las como fazendo parte de uma teoria que busca explicar um fenômeno, e que sua existência real não é garantida pelo conhecimento científico.

Sabe-se que os modelos procuram dar conta de uma realidade incognoscível e que são constructos teóricos úteis na representação da realidade. Mais do que representar o real, os modelos são ferramentas que auxiliam o cientista na compreensão de um dado fenômeno. 


\title{
Whiggismo (emergente)
}

A chamada História da Ciência Whig descreve os fatos históricos, em função do conhecimento presente. Não busca compreender os fatos de acordo com as concepções filosóficas, o momento e condições do período em que são estudados. Julga o passado a partir do presente.

Como exemplo cita-se o seguinte excerto: "A afirmação final de Dalton não é verdadeira, a nossos olhos modernos, uma vez que ela se choca com a hipótese de Avogadro, que apareceria em 1.811, a qual afirma que volumes iguais de gases diferentes contêm o mesmo número de moléculas". (FILGUEIRAS, 2004, p. 43). O autor aqui vê o passado a partir do presente.

Esse fato também está presente em outro artigo (GOUVEIA-MATOS, 1997): "A implantação das teorias que levaram às atuais concepções sobre as doenças exigia, portanto, a superação de três obstáculos para entende-las e preveni-las...". (GOUVEIAMATOS, 1997, p. 21). Do mesmo artigo extrai-se outro excerto que exemplifica a visão aqui discutida.

\begin{abstract}
Além disso, como as teorias químicas de então eram totalmente incipientes (ainda não estavam estabelecidos conceitos como os de molécula, peso molecular, ligações químicas etc.), suas conclusões tinham de se fundamentar em forte rigor lógico-experimental, o que transformou Pasteur num dos maiores experimentalistas de todos os tempos. (GOUVEIA-MATOS, 1997, p. 21).
\end{abstract}

Percebe-se no trecho acima a avaliação do que era conhecido então por meio do presente. $O$ autor não procura conceber o conhecimento como dependente do contexto da época, onde outras concepções guiavam os cientistas em busca das descobertas.

No entanto, salienta-se que esse é um modo de fazer História da Ciência. Em um dos artigos (FERREIRA; PEDUZZI, 2014), por exemplo, uma visão deformada surge devido à perspectiva histórica adotada pelo epistemólogo em questão, Bachelard, que defendia a tese de que a história deveria ser avaliada a partir do conhecimento presente. Julga-se tal concepção inadequada pelo fato de não levar em consideração aspectos externos do fazer científico, que conforme visto, influenciam a Ciência.

\section{Exemplos de visões de enfrentamento}

Nessa seção são apresentados exemplos cada uma das Visões de Enfrentamento. Constitui-se por oito categorias definidas a priori e duas emergentes, totalizando dez categorias.

\section{Ciência influenciada por fatores externos}

Os fatores externos influenciam o desenvolvimento científico e definem, muitas vezes, os rumos que irá tomar.

Em um artigo (CHAGAS, 2001), o autor cita os trabalhos desenvolvidos por van't Hoff sobre petrologia, destacando que os estudos iniciaram-se a partir de um projeto que visava estudar a formação dos depósitos salinos de Stassfurt, apresentando, mesmo que brevemente, os aspectos externos que influenciam o fazer científico: "Em Berlim, van't Hoff 
propõe e dirige um amplo projeto de estudos envolvendo a Academia de Ciências da Prússia, a Universidade de Berlim, o Sindicato das Mineradoras e Indústrias do Potássio (Kali-Syndikat) e outras instituições [...]" (CHAGAS, 2001, p. 26).

Em relação ao modo como as relações econômicas e políticas influenciam as pesquisas científicas, o Gouveia-Matos (1997) mostra como Pasteur dependeu desses fatores para o desenvolvimento de seu trabalho: "Os produtos agrícolas tinham em 1863 um peso preponderante na economia francesa, e Pasteur foi convidado - e financiado - pelo imperador Napoleão III a estudar as doenças do vinho". (GOUVEIA-MATOS, 1997, p. 21). Em outro trecho, essa relação é novamente salientada: "A associação com o setor agropecuário foi o que veio a estabelecer na obra de Pasteur a relação direta entre doença e microrganismos". (GOUVEIA-MATOS, 1997, p. 21).

Machado (2015) apresenta um estudo no qual relaciona os produtos naturais vegetais amazônicos e os laboratórios de ensino e pesquisa da Escola de Chimica Industrial do Pará, sendo possível compreender o fato de que os desenvolvimentos científicos estão estreitamente ligados a questões de ordem política, econômica e social.

\footnotetext{
Ao transitarem entre esses diferentes atores sociais desde o final do século XIX, os produtos naturais amazônicos produzem um profundo impacto local e externo, gerando desdobramentos cognitivos, políticos, econômicos, sociais e epistemológicos (MACHADO, 2015, p. 81).

Suas preocupações são mais facilmente compreendidas quando fica claro que se tratava de uma instituição vinculada à Associação Comercial do Pará e mantida por verbas oriundas do Ministério da Agricultura, buscando assim apresentar algum retorno de curto prazo às instituições que mantinham a Escola (MACHADO, 2015, p. 85).
}

Assim, percebe-se como a Ciência está inserida na sociedade, influenciando-a e sendo influenciada por ela, tendo sua história muitas vezes entrelaçada pela economia, política e religião.

\section{Ciência como atividade coletiva}

A categoria Ciência como atividade coletiva compreende os trabalhos que buscam dar visibilidade ao aspecto coletivo da construção do conhecimento científico que, em certa medida, depende de mentes brilhantes, mas que, antes de tudo, depende da existência de uma comunidade científica.

Oki (2000), ao citar diversos cientistas que tiveram grande importância para o entendimento dos fenômenos elétricos, enfatiza o aspecto coletivo da construção do conhecimento científico:

As pesquisas realizadas por Berzelius relacionadas ao uso de corrente elétrica para produzir transformações químicas ajudaram o químico e físico inglês Michael Faraday (1791-1867) a encontrar relações de proporcionalidade entre a quantidade de matéria decomposta e a quantidade de eletricidade utilizada, estimulando estudos quantitativos envolvendo a eletricidade. (OKI, 2000, p. 37).

No excerto acima, percebe-se como o trabalho de diferentes cientistas é necessário para o avanço do conhecimento científico. Baseado em obras de outros autores é que os 
cientistas desenvolvem suas pesquisas, continuando-as ou refutando-as fazendo com que explicações mais abrangentes dos fenômenos físicos possam ser construídas.

Melzer e Aires (2015) também salientam a importância dos aspectos relacionados à ciência como resultado de um trabalho de desenvolvimento histórico e coletivo quando apresentam a história do desenvolvimento da teoria atômica. No trecho abaixo é possível compreender o fato de que o conhecimento científico se desenvolve a partir de questões colocadas por vários pesquisadores, e que a Ciência, é por essência, uma atividade coletiva.

"E um segundo momento, através de seus estudos sobre misturas gasosas (1802 e 1805), com todas as discussões e críticas feitas pelos seus contemporâneos que o fizeram analisar e conceber uma união entre a proposta Newtoniana de partícula com as propostas de afinidade química, ambas apresentadas em sua época (MELZER; AIRES, 2015, p. 66-67)".

Assim, nos artigos há a preocupação em apresentar os cientistas como membros de uma comunidade que busca solucionar os problemas determinados pelo paradigma vigente. As questões científicas de uma determinada época não são determinadas por uma dúvida que assola um único cientista, mas são sim, problemas atestados pela coletividade de praticantes da área.

\section{Observação influenciada por uma teoria}

Essa categoria é formada por artigos que destacam que não há observação neutra, sendo esta sempre influenciada por uma teoria.

A presença de paradigmas é bastante nítida nas constatações da autora de um dos artigos (OKl, 2000), já que cita diversas vezes como o desenvolvimento de uma teoria norteou pesquisas que estavam relacionadas ao tema:

"Átomos com um mesmo tipo de carga elétrica não podiam se combinar e, portanto, não seria possível a existência de moléculas diatômicas homonucleares como H2, O2, N2, Cl2. Esta teoria eletroquímica constituiu a base teórica do sistema dualístico proposto por Berzelius, e influenciou a produção científica da química no século 19. [...] A investigação da natureza íntima da matéria intensificou-se durante todo o século 19, contribuindo para a consolidação da teoria atômica e a descoberta das partículas subatômicas que, efetivamente, comprovarão as hipóteses sobre a natureza elétrica da matéria, anteriormente formuladas. (OKI, 2000, p. 37)".

Percebe-se no trecho destacado como as pesquisas são orientadas por paradigmas, de acordo com a perspectiva kuhniana. Sendo assim, não há pesquisa que não seja guiada por um referencial teórico, de maneira que muitas vezes, um paradigma vigente em uma determinada época é que irá definir quais pesquisas serão realizadas, como destacado no excerto, onde o sistema proposto por Berzeluis influenciou toda a produção de um século.

A formação de um pesquisador também pode influenciar a maneira pela qual este compreende determinados fenômenos. Este é o caso de John Dalton que, segundo o Melzer e Aires (2015), por ter uma formação matemática, pode ter dado ao seu modelo atômico um caráter diferenciado.

"[...] John Dalton marcou o desenvolvimento da teoria atômica, apoiado

[...] por uma série de fatores de ordem profissional e de opções teóricas 
assumidas por Dalton. O Primeiro destes fatores refere-se ao fato de Dalton não ter, originalmente, uma formação química, mas sim matemática, que [...], pode ter influenciado por uma perspectiva diferente de sua percepção dos fenômenos físicos e químicos (MELZER; AIRES, 2015, p. 65)".

Outro trecho destaca o fazer científico influenciado por uma teoria, mostrando como o programa de pesquisa de Pasteur foi influenciado a partir de uma sugestão de Biot.

\begin{abstract}
"Sua tese de doutorado, defendida em 1847, constava de duas partes: uma em química, sobre a capacidade de saturação do ácido arsenioso, e outra em física, intitulada 'Estudo dos fenômenos relativos à polarização rotatória dos líquidos' - sendo esta última, na verdade, segundo o próprio Pasteur, um programa de pesquisa para estudar, a partir de uma sugestão de Biot, a causa do estranho fenômeno dos ácidos tártarico e paratartárico. (GOUVEIA-MATOS, 1997, p. 20)".
\end{abstract}

Assim, percebe-se que Pasteur não estudou os ácidos tártarico e paratartárico porque percebeu um precipitado diferente do esperado em suas experiências, mas sim devido ao fato de conhecer os trabalhos de Biot sobre o tema.

A análise dos artigos permite reconhecer o fato de os fenômenos não serem "dados", mas sim, construídos por meio de uma teoria.

\title{
Pluralismo metodológico
}

De maneira geral, concebe-se a Ciência como não possuindo um método específico. Na tentativa de definição de um único método, os Filósofos da Ciência falharam em tentar categorizar toda a Ciência como uma atividade procedimental de passos específicos.

Outro artigo (MARTORANO; MARCONDES, 2009) destaca ao longo do texto a não existência de um único método científico.

"De acordo com a filosofia da Ciência, não existe um método científico único que possa indicar quais são os passos que os cientistas devem dar em direção a construção de teorias e leis científicas. Vários filósofos abordam o desenvolvimento da Ciência de diferentes perspectivas, propondo diferentes caminhos para a construção do conhecimento cientifico. (MARTORANO; MARCONDES, 2009, p. 342)".

Outro artigo (LÔBO, 2007) também busca corroborar este fato.

"Pode-se inferir que, embora o progresso científico das Ciências físicas tenha se dado na direção de uma racionalidade cada vez mais complexa, várias perspectivas filosóficas coexistiram e podem ainda coexistir no processo de produção científica. (LÔBO, 2007, p. 94)".

Os excertos acima dizem respeito à questão do contexto da descoberta, que trata do modo como as ideias surgem. Estas não seguem um protocolo, tampouco podem ser procedimentalizadas. O pluralismo metodológico é que torna a Ciência uma atividade com tamanha fecundidade. 
Em se tratando de História da Ciência, têm-se vários exemplos de pluralismo metodológico. Como em Chagas (2011), onde o autor cita a estatística, que pode ser considerada diferente de alguns métodos utilizados pela Ciência, já que ela aborda os problemas sob um outro viés: "Os teóricos procuraram resolver o problema por meio de uma abordagem estatística". (CHAGAS 2011, p. 11).

Nesse mesmo artigo, o autor cita como Jean Perrin calculou a constante de Avogadro por vários métodos: "No último capítulo, Conclusions, Perrin apresenta uma tabela com os valores da constante de Avogadro determinada por vários métodos" (CHAGAS, 2011, p. 14), indicando assim a presença do pluralismo metodológico característico da Ciência.

\section{Caráter histórico e dinâmico da Ciência}

Os artigos que apresentam o conhecimento científico mutável, dinâmico e com uma historicidade inerente, foram enquadrados nessa categoria.

Em um artigo de Oki (2000), a autora salienta que, como na frase a seguir, o conhecimento científico não é uma verdade, mas uma tentativa de explicação dos fenômenos: "Ainda neste século surgiu a proposta do físico francês Charles François de Cisternay Dufay (1692-1739) de divisão da eletricidade em dois tipos: resinosa e vítrea, levando em conta a natureza do material atritado". (OKI, 2000, p. 35). A expressão em destaque salienta o fato de que os cientistas tentam dar explicações para os fenômenos, demonstrando, portanto, sua suscetibilidade a mudanças.

O mesmo fato é constatado em um artigo (MARTORANO; MARCONDES, 2014), que trata do desenvolvimento histórico da Cinética Química: "Portanto, por meio da substituição de um programa de investigação por outro, pode-se perceber quanto o entendimento envolvido na cinética química mudou e que provavelmente continuará mudando nos próximos anos". (MARTORANO; MARCONDES, 2014, p. 125).

\section{Unificação do conhecimento científico}

Nessa categoria, os artigos buscam mostrar como as diferentes áreas da Ciência não são independentes, sendo que uma área influencia o desenvolvimento da outra.

Em um artigo (CHAGAS, 1999), o autor apresenta as diferentes teorias ácido-base do século XX e como cada teoria nova buscava englobar todas as explicações dadas pelas antigas, além de fornecerem novos embasamentos para futuras pesquisas: "Esta teoria foi muito importante, pois além de dar conta de um grande número de fenômenos já conhecidos, provocou o desenvolvimento de várias linhas de pesquisa, inclusive contribuindo para estabelecer as bases científicas da química analítica". (CHAGAS, 1999, p. 28),

Assim, os artigos pertencentes a essa categoria são os que procuram mostrar que a Química, assim como a Física, a Biologia e todas as outras Ciências, não são formas de conhecimento estanques, sem conexão com outras áreas. As diferentes Ciências não evoluem independentemente, e sim em conjunto, sendo que os desenvolvimentos que fornecem as bases para a estruturação de uma área muitas vezes causam mudanças de paradigmas em outras. 


\title{
Rupturas e/ou controvérsias científicas
}

As rupturas e/ou controvérsias científicas representam o pensamento divergente, as diferentes opiniões a respeito das causas dos fenômenos naturais, tão caras a construção do conhecimento científico.

Considere-se o excerto abaixo:

\begin{abstract}
"As pesquisas de Dufay levaram à formulação da teoria dos dois fluidos que considerava como neutra a matéria formada por iguais quantidades dos fluidos vítreo e resinoso. A eletrização aconteceria caso um corpo ganhasse uma quantidade em excesso de um destes fluidos e perdesse a mesma quantidade do outro, de modo que a quantidade total dos fluidos permanecesse a mesma (Laidler, 1998). Discordando desta teoria, o cientista americano Benjamin Franklin (1706-1790) propôs outra teoria do fluido único. Um corpo não eletrificado deveria possuir uma quantidade normal de fluido elétrico. Quando presente em excesso, este imprimiria uma carga positiva ao corpo e a sua defiCiência implicaria em uma carga negativa. (OKI, 2000, p. 35)".
\end{abstract}

Por meio do excerto acima, identifica-se como o pensamento divergente se faz tão importante à construção do conhecimento científico, já que permite aos cientistas perceberem aspectos de um determinado fenômeno que o outro não havia levado em consideração. Como no caso das rupturas, onde uma explicação que até então era tida como a única possível, é confrontada com dados que não corroboram com aquela teoria. Nesse caso, novas explicações são necessárias, podendo inclusive ir contra a teoria vigente.

Outro fragmento que também apresenta o aspecto divergente presente na construção do conhecimento científico é o trecho onde a autora (OKI, 2000) cita Volta, que discordando das opiniões de Galvani, utiliza de sua influência no meio acadêmico para propor uma nova teoria, podendo-se perceber claramente que a Ciência também é influenciada por fatores externos ao fazer científico:

"As pesquisas sobre eletricidade animal estimularam novos estudos realizados por Alessandro Volta (1745-1827), professor da Universidade de Pavia, que discordando da explicação de Galvani, supôs que a eletricidade poderia ser gerada pela conexão entre os dois diferentes metais colocados em contato com o animal. Este pesquisador reconheceu que o animal morto agia meramente como condutor, mas, de modo equivocado, achava que a eletricidade gerada era devido ao contato entre dois metais diferentes, propondo a 'teoria da eletricidade por contato', que foi aceita por muitos anos em virtude do prestígio que gozava o seu autor no meio cientifico. (OKI, 2000, p. 36)".

Nesse excerto destacamos também a influência que aspectos externos ao fazer científico exercem sobre o desenvolvimento da Ciência. No caso da controvérsia entre Volta e Galvani, elucidado pela autora, a teoria proposta por Volta foi aceita não apenas por fornecer uma explicação mais abrangente dos fenômenos elétricos, mas também em virtude deste cientista gozar de prestígio no meio científico. 


\section{Ciência como atividade imaginativa e criativa}

Essa categoria busca apresentar os artigos que salientam um aspecto muito importante presente na Ciência e também nos cientistas: a imaginação e criatividade. A Ciência não segue passos rígidos, algorítmicos, conforme discutido na seção que trata do método científico. Ela depende em grande medida do contexto da descoberta, onde aspectos não apenas filosóficos e justificadores são levados em conta. Nesse sentido, a imaginação exerce um papel preponderante no desenvolvimento científico, já que é por meio dela que o conhecimento pode avançar por caminhos antes inimagináveis.

Outro artigo (FARIAS, 2001), ao relatar o papel da intuição de Alfred Werner, mostra como a Ciência não é algorítmica: "A ponte necessária para se passar de uma teoria estabelecida, porém imperfeita, para outra, ousadamente inovadora, porém ainda não totalmente passível de comprovação, foi arquitetada pela intuição de Werner". (FARIAS, 2001, p. 32). O trecho em destaque também se relaciona com as rupturas e controvérsias, já que muitas vezes, ao apresentar uma teoria inovadora, o cientista é forçado a romper com o paradigma dominante. Assim, não apenas a Ciência é dependente de grandes mentes, mas também do contexto em que é desenvolvida.

Os excertos abaixo mostram como a subjetividade é inerente ao fazer científico, sendo impossível que tal aspecto seja deixado de lado ao se fazer Ciência. A questão também se relaciona com o fato de uma observação ser influenciada por uma teoria, mostrando mais uma vez como a subjetividade está presente em todas as etapas do processo científico.

"Finalmente, entende-se o conhecimento científico como uma forma de compreender o mundo, sem ser uma verdade, possuindo status temporal. Os novos conhecimentos, por sua vez, seriam produzidos por atos criativos da imaginação, ligados a métodos de investigação e validados por comunidades científicas ou outros espaços de poder, emergentes em nosso tempo, como as mídias. (LOPES et al., 2007, p. 7)".

"Bachelard questiona a objetividade no trabalho dos cientistas. Contrariando a positividade atribuída à pesquisa científica, procura mostrar, em suas obras - em especial no livro A Filosofia do Não - como o caráter subjetivo pode interferir na prática científica. (LÔBO, 2007, p. 91)".

\section{Modelos como representação da realidade (emergente)}

A categoria 'modelos como representação da realidade (emergente)' considera que um modelo é uma idealização simplificada de um sistema que possui maior complexidade. Assim, os modelos são tidos como uma etapa essencial do fazer científico e envolvem capacidade de abstração, imaginação e criatividade. Sendo assim, entende-se que os modelos são "destinados a representar uma realidade, ou alguns de seus aspectos, a fim de torná-los descritíveis quantitativa e qualitativamente e, algumas vezes, observáveis". (SAYÃO, 2001, p. 83, grifo nosso).

O artigo de Thiemann (2003) é um exemplo de como os modelos são importantes para a compreensão dos fenômenos. Ele relata o percurso da elaboração do modelo de dupla hélice do DNA por Watson e Crick.

"Depois de seguidas tentativas, em 28 de fevereiro de 1953 Watson fez modelos das bases (A, C, G e T) em pedaços de cartão (Figura 14), na tentativa de identificar possíveis modos de interação. Percebeu então que 
os pares A - T e C - G formavam ligações de hidrogênio, resultando em pares de dimensões quase idênticas, o que permitiria que a hélice se mantivesse com o mesmo diâmetro, independente do pareamento de bases no interior. Esse arranjo satisfez à regra proposta por Chargaff, pela qual $\mathrm{A}=\mathrm{T}$ e $\mathrm{C}=\mathrm{G}$. Depois de trabalharem sobre esse modelo por mais alguns dias, refinando o mesmo para que fosse coerente com os dados de difração de raios $X$, eles chegaram ao modelo final. ((THIEMANN, 2003, p. 18)".

Sobre o papel dos modelos na construção do conhecimento científico, Islas e Pesa (2001) argumentam que o fenômeno em estudo pode ser representado sob diversas formas e se escolhe uma que seja mais adequada ao estudo que está sendo realizado. Essa escolha implica uma simplificação do fenômeno estudado, visto que alguns aspectos serão tomados na construção do modelo. A simplificação, dessa forma, é uma questão importante a ser considerada na construção dos modelos porque, por meio dela, é possível representar a realidade.

Chagas (2011) apresenta um trecho onde é possível verificar esta constatação, já que explica que não há nenhuma prova em relação à realidade molecular e nem uma maneira de demonstrá-la, mas que é uma maneira adequada de explicação de uma enorme gama de fatos.

\footnotetext{
"Uma conclusão a que podemos chegar é a seguinte: não há nenhuma prova ou experimento crucial com relação à realidade molecular. O que há é um conjunto enorme de fatos que só podem ser explicados em seu conjunto pela teoria atômico-molecular. (CHAGAS, 2011, p. 15)".
}

Islas e Pesa (2003) ainda comentam que a validação de um modelo construído não se dá apenas pela sua adequação como representação da realidade, mas também pela coerência sistêmica entre as estruturas dos modelos e teorias que são aceitas pela comunidade científica.

\section{Ciência como atividade humana (emergente)}

A categoria Ciência como atividade humana (emergente) ressalta o fato de que a Ciência é feita por pessoas, seres humanos comuns, que cometem erros, utilizam de suas crenças e expectativas para elaborar e legitimar suas ideias, têm qualidades e defeitos, etc. Essa categoria emerge do fato de alguns artigos analisarem características pessoais dos cientistas, apresentadas como alguns dos aspectos essenciais no fazer científico. Sendo assim, é de suma importância frisar que a Ciência é uma atividade humana que envolve questões outras que as puramente técnicas.

O excerto a seguir, que mostra alguns aspectos pessoais de Alfred Werner, corrobora a influência de aspectos pessoais no fazer Ciência. "Deve-se lembrar que Werner não tinha como únicas marcas características a intuição e a impulsividade. Ele era também persistente". (FARIAS, 2001, p. 32).

Por meio de todas estas categorias podemos verificar como a Ciência se considerada apenas em seus aspectos internos não dá conta de toda a complexidade que envolve o empreendimento científico. É necessário que professores e alunos se deem conta deste fato e compreendam que a Ciência é uma atividade que merece ser estudada em si, considerando seus aspectos procedimentais e atitudinais. 
Salienta-se aqui a quantidade de publicações referentes à HFC no Ensino de Química brasileiro. Apesar de alguns artigos conterem erros historiográficos, conforme observou-se nas visões deformadas, há material suficiente e adequado para que o professor de Química possa utilizar a abordagem HFC tanto em nível médio quanto em nível superior de Ensino. Por meio de uma formação adequada, o professor pode encontrar as potencialidades presentes em cada um dos artigos, de modo que, por mais que os trabalhos mostrem deficiências, isto não se torne um empecilho para que a Química seja apresentada em seus aspectos históricos e filosóficos. Compreender o modo como a Química opera, o papel do cientista, os fatores sociais que a determinam, enfim, toda a complexidade do empreendimento científico pode ajudar a tornar o Ensino de Ciências mais atraente, interessante e motivador, dando significado ao que está sendo ensinado. É nesse sentido que a abordagem HFC oferece enorme potencial para um aprendizado mais significativo.

\section{Considerações finais}

Este trabalho este trabalho teve como objetivo investigar quais visões sobre Natureza da Ciência ( $\mathrm{NdC}$ ) são veiculadas em artigos publicados em periódicos nacionais que tratam da educação em ciências, buscando fornecer alguns elementos que permitam ao professor analisar aspectos da HFC presentes nesses artigos. Destacamos que não se pretende que o professor de Ciências/Química seja um historiador da Ciência, mas que saiba de alguns aspectos básicos relativos à HFC de modo a não transmitir aos alunos informações simplistas e reducionistas sobre o que é o empreendimento científico e, principalmente, como a Ciência é construída. Nesse sentido, concordamos com o fato de que é preferível pouca informação histórica de qualidade ao invés de uma História da Ciência superficial e distorcida.

Em relação aos resultados da pesquisa, no que se refere às Visões Deformadas sobre a NdC, verificamos que o maior percentual de artigos correspondeu a categoria 'Ciência não influenciada por fatores externos'. O predomínio desta categoria está relacionado à uma visão de Ciência internalista, influência de uma historiografia da ciência mais antiga, originária do paradigma empírico indutivista, no qual considerava-se que a ciência se desenvolvia à parte do contexto social, econômico, político e cultural.

Já em relação às Visões de Enfrentamento, houve predomínio da categoria 'Caráter histórico e dinâmico da Ciência', tal visão denota a ideia de que a atividade científica não é rígida, algorítmica, imutável e regida por leis eternas, e que os cientistas não são seres geniais que em momentos de insight fazem grandes descobertas. É possível, por meio dessas concepções, que os alunos compreendam a Ciência como uma atividade essencialmente humana, com uma história de rupturas e controvérsias construída por homens e mulheres ao longo dos séculos.

Consideramos que, mesmo havendo ainda a presença visões deformadas nos artigos, houve predomínio das categorias de enfrentamento, o que denota que a área de ensino de ciências vem trazendo elementos que podem subsidiar os professores no enfrentamento de muitos dos problemas relacionados ao ensino de ciências, uma vez que compreender a $\mathrm{NdC}$ permite que os alunos construam visões mais adequadas sobre a Ciência e à prática científica, além de impactar positivamente as atitudes e interesses destes frente à Ciência. 


\section{Referências}

ABD-EL-KHALICK, Fouad. Teaching with and about nature of science, and science teacher knowledge domains. Science \& Education, v. 22, p. 2087-2107, 2013.

BELTRAN, Maria Helena Roxo; SAITO, Fumikazu; TRINDADE, Lais dos Santos Pinto. História da Ciência para a formação de professores. São Paulo: Editora Livraria da Física, 2014.

FORATO, Thaís Cyrino de Mello; PIETROCOLA, Maurício; MARTINS, Roberto de Andrade. Historiografia e natureza da Ciência na sala de aula. Caderno Brasileiro de Ensino de Física, Florianópolis, v. 28, n. 1, p. 27-59, 2011.

GANDOLFI, Haira Emanuela; FIGUEIRÔA, Silvia Fernanda de Mendonça. A história da Ciência e o ensino interdisciplinar: uma revisão de propostas e contribuições. In: IX Encontro Nacional de Pesquisa em Educação em Ciências, 2013, Águas de Lindóia. Atas .... Águas de Lindóia: ABRAPEC, 2013. p. 1-8.

GIL-PÉREZ, Daniel. et al. Para uma imagem não deformada do trabalho científico. Ciência \& Educação, Bauru, v. 7, n. 2, p. 125-153, 2001.

HENKE, Andreas; HÖTTECKE, Dietmar. Physics teachers' challenges in using history and philosophy of Science in teaching. Science and Education, v. 24, p. 349-385, 2015.

HÖTTECKE, Dietmar; HENKE, Andreas; RIESS, Falk. Implementing history and philosophy in Science teaching: strategies, methods, results and experiences from the European HIPST Project. Science and Education, v. 21, n. 9, p. 1.233-1.261, 2012.

HÖTTECKE, Dietmar; RIESS, Falk. Developing and implementing case studies for teaching Science with the help of history and philosophy. Paper presented at the Tenth International History, Philosophy and Science Teaching Conference. South Bend, USA, 2009.

HÖTTECKE, Dietmar; SILVA, Cibelle Celestino. Why implementing history and philosophy in school science education is a challenge: an analysis of obstacles. Science and Education, $v$. 20, n. 3-4, p. 293-316, 2011.

MARTINS, Roberto de Andrade. Introdução: A história das Ciências e seus usos na educação. In: SILVA, Cibele Celestino. (Org.). Estudos de história e filosofia das Ciências: subsídios para aplicação no ensino. São Paulo: Livraria da Física, 2006, p. xvii-xxx.

MATTHEWS, Michael. História, filosofia e ensino de Ciências: a tendência atual de reaproximação. Caderno Catarinense de Ensino de Física, Florianópolis, v. 12, n. 3, p. 164214, dez. 1995.

McCAIN, Kevin. Explanation and the nature of scientific knowledge. Science and Education, v. 24, p. 827-854, 2015.

McCOMAS, William. Seeking historical examples to illustrate key aspects of the nature of science. Science and Education, v. 17, n. 2-3, p. 249-63, 2008.

McCOMAS, William; KAMPOURAKIS, Kostas. Using the history of biology, chemistry, geology, and physics to illustrate general aspects of nature of Science. Review of Science, Mathematics and ICT Education, v. 9, n. 1, p. 47-76, 2015. 
MOURA, Breno Arsioli. Formação crítico-transformadora de professores de Física: uma proposta a partir da História da Ciência. 2012. 309 f. Tese (Doutorado) - Faculdade de Educação, Instituto de Física, Instituto de Química, Instituto de BioCiências, Universidade de São Paulo, São Paulo, 2012.

MOURA, Breno Arsioli. O que é natureza da Ciência e qual sua relação com a história e filosofia da Ciência. Revista Brasileira e História da Ciência, v. 7, n. 1, p. 32-46, 2014.

PEDUZZI, Luiz O. Q.; MARTINS, André; FERREIRA, Juliana (Orgs.). Temas de História e Filosofia da Ciência e Ensino. Natal: EDUFRN, 2012.

RAICIK, Anabel Cardoso; PEDUZZI, Luiz O. Q. O contexto da descoberta e o contexto da justificativa em sala de aula. In: Conferencia latinoamericana del international, history and philosophy of science teaching group IHPST, 3., 2014, Santiago do Chile. Comunicação oral... Santiago do Chile: IHPST, 2014. p. 23-33.

SAITO, Fumikazu. "Continuidade" e "descontinuidade": o processo da construção do conhecimento científico na História da Ciência. Revista da FAEEBA - Educação e Contemporaneidade, Salvador, v. 22, n. 39, p. 183-194, 2013.

SILVA, Elda Cristina Carneiro da. A teoria celular em livros didáticos de biologia: uma análise a partir da abordagem histórico-filosófica da Ciência. 2014. 292 f. Dissertação (Mestrado em Educação em Ciências e em Matemática) - Setor de Ciências Exatas, Universidade Federal do Paraná, Curitiba, 2014.

TALA, Suvi; VESTERINEN, Veli-Matti. Nature of Science contextualized: studying nature of Science with scientists. Science \& Education, v. 24, p. 435-457, 2015.

VESTERINEN, Veli-Matti; AKSELA, Maija. Design of chemistry teacher education course of nature of science. Science \& Education, v. 22, p. 2.193-2.225, 2013. 


\section{Apêndice $a$ - artigos analisados}

BAGATIN, O. et al. Rotação de luz polarizada por moléculas quirais: uma abordagem histórica com proposta de trabalho em sala de aula. Química Nova na Escola, n. 21, p. 3438, 2005.

CHAGAS, A.P. 100 anos de Nobel - Jacob Henricus van't Hoff. Química Nova na Escola, n. 14, p 25-27, 2001.

CHAGAS, A.P. Existem átomos? (abordando Jean Perrin). História da Ciência e Ensino: construindo interfaces, v. 3, p. 7-16, 2011.

CHAGAS, A.P. Teorias ácido-base do século XX. Química Nova na Escola, n. 9, p. 28-30, 1999.

FARIAS, R.F. Werner, Jørgensen e o papel da intuição na Evolução do Conhecimento Químico. Química Nova na Escola, n. 13, p. 29-33, 2001.

FERREIRA, L.M. PEDUZZI, L.O.Q. As intuições Atomísticas de Bachelard. Revista Brasileira de Pesquisa em Educação em Ciências, v.14, n.3, p. 119-137, 2014.

FILGUEIRAS, C.A.L. Duzentos anos da teoria atômica de Dalton. Química Nova na Escola, n. 20, p.38-44, 2004.

GORRI, A.P. SANTIN FILHO, O. Representação de temas científicos em pintura do século XVIII: um estudo interdisciplinar entre Química, História e Arte. Química Nova na Escola, v. 31, n. 3, p. 184-189, 2009.

GOUVEIA-MATOS, J.A.M. Pasteur - Ciência para ajudar a vida. Química Nova na Escola, n. 6, p. 20-22, 1997.

LÔBO, S.F. O Ensino de Química e a formação do educador químico, sob o olhar bachelardiano. Ciência \& Educação, v. 14, n. 1, p. 89-100, 2007.

LOPES, C.V.M. et al. Concepções de professores de Química sobre a natureza do conhecimento científico. Acta Scientiae, v. 9, n. 1, p. 3-16, 2007.

MACHADO, J.R.C. Natureza e Cultura entrelaçadas: o Boletim científico da Escola de Chimica Industrial do Pará. Amazônia: Revista de Educação em Ciências e Matemática, v.11, n. 22, p.61-78, 2015.

MARTORANO, S.A.A. MARCONDES, M.E.R. As concepções de Ciência dos livros didáticos de Química, dirigidos ao Ensino Médio, no tratamento da Cinética Química no período de 1929 a 2004. Investigações em Ensino de Ciências, v. 14, n.3, p. 341 - 355, 2009.

MARTORANO, S.A.A. MARCONDES, M.E.R. Investigando a abordagem do tema Cinética Química nos livros didáticos dirigidos ao Ensino Médio a partir das ideias de Imre Lakatos. Acta Scientiae, v. 16, n. 1, p. 114-132, 2014.

MEDEIROS, A. Aston e a descoberta dos isótopos. Química Nova na Escola, n. 10, p. 32-36, 1999.

MELZER, E.; AIRES, J.A. A História do desenvolvimento da teoria atômica: um percurso de Dalton a Bohr. Amazônia: Revista de Educação em Ciências e Matemática, v.11, n. 22, p.6277, 2015. 
OKI, M.C.M. A eletricidade e a Química. Química Nova na Escola, n. 12, p. 34-37, 2000.

ROQUE, N.F. Uma festa no céu - peça em um ato focalizando o desenvolvimento da Química a partir do século XVIII. Química Nova na Escola, n. 25, p. 30-33, 2007.

THIEMANN, O.H. A descoberta da estrutura do DNA: de Mendel a Watson e Crick. Química Nova na Escola, n. 17, p. 13-19, 2003. 